\title{
ASSESSMENT OF LANDSLIDE RISK USING GIS AND STATISTICAL METHODS IN KYSUCE REGION
}

\author{
MÁRIA BARANČOKOVÁ, PAVOL KENDERESSY
}

Institute of Landscape Ecology, Slovak Academy of Sciences, Štefánikova 3, P.O.Box 254, 81499 Bratislava, Slovak Republic; e-mail: maria.barancokova@savba.sk, pavol.kenderessy@savba.sk

\begin{abstract}
Barančoková M., Kenderessy P.: Assessment of landslide risk using GIS and statistical methods in Kysuce region. Ekológia (Bratislava), Vol. 33, No. 1, p. 26-35, 2014.

The landslide susceptibility was assessed based on multivariation analysis. The input parameters were represented by lithology, land use, slope inclination and average annual precipitation. These parameters were evaluated as independent variables, and the existing landslides as dependent variables. The individual input parameters were reclassified and spatially adjusted. Spatial analysis resulted in 15988 combinations of input parameters representing the homogeneous condition unit (HCU). Based on the landslide density within individual units, the HCU polygons have been classified according to landslide risk into stable, conditionally stable, conditionally stable and unstable (subdivided into low, medium and high landslide risk). A total of 2002 HCUs were affected by landslides, and the remaining 13986 were not affected. The total HCU area affected by landslides is about $156.92 \mathrm{~km}^{2}(20.1 \%)$. Stable areas covered $623.01 \mathrm{~km}^{2}(79.8 \%)$, and conditionally stable areas covered $228.77 \mathrm{~km}^{2}$ (29.33\% out of this area). Unstable areas were divided into three levels of landslide risk - low, medium and high risk. An area of $111.19 \mathrm{~km}^{2}(14.3 \%)$ represents low landslide risk, medium risk $29.7 \mathrm{~km}^{2}(3.8 \%)$ and $16.01 \mathrm{~km}^{2}(2 \%)$ represents high risk. Since Zlín Formation lithological unit covers approximately one-third of the study area, it also influences the overall landslide risk assessment. This lithological formation covers the largest area within all landslide risk classes as well as in conditionally stable areas. The most frequent slope class was in the range of 14-19. The higher susceptibility of Zlín Formation to landslides is caused mainly by different geomorphological value of claystone and sandstone sequence. The higher share of claystone results in higher susceptibility of this formation to exogenous degradation processes.
\end{abstract}

Key words: landslide risk assessment, GIS.

\section{Introduction}

Slope deformations are one of the most common geodynamic phenomena in Slovakia. Until the year 2008, there were 21190 slope deformations recorded in the whole country (Kopecký et al., 2008).

Natural and anthropogenic-induced landslides significantly determine the development of regions where they occur. They represent risk and often cause extensive damage to houses and loss of human lives. Hence it is necessary to map and evaluate all aspects of landslide hazards. The most important step in this process is the selection of appropriate methodology 
followed by landslide susceptibility map. In order to evaluate landslide hazard it is important to determine the causal factors of potential slope instability and landslide occurrence. Determination of factors causing the occurrence of slope deformations in the past helps predict the occurrence of new deformations.

The most relevant factors determining the occurrence of landslides are geology (lithology, tectonic, seismic and structural conditions), geomorphological conditions and topography (morphometrical characteristics, slope and altitude), hydrological and climate conditions and factors related to anthropogenic factors represented by landcover structure and land use.

The impact of landslides on geomorphological character of potentially risky areas reflects the character of environment quality - geology, underground water, geomorphology and their mutual interaction as well as interaction with external factors.

Paleogene complexes of fast eroding bunchy flysch represent a good condition for formation of thick deluvial cover. The extensive division of deluvial layers and pre-quaternary substrate material strongly impacted by solifluction processes provide suitable conditions for occurrence of slip planes and activation of landslides. Each slope is characterised by a certain level of activity. Decrease in slope stability is often caused by exogenous natural factors such as rainfall anomaly, rock weathering, slope load, seismic activity, slope inclination, bank erosion, etc. Besides nature-induced factors, anthropogenic factors (linear construction activities) also play an important role in landslides activation.

\section{Material and methods}

The landslide hazard has been a topic for many research studies like Carrara (1983, 1988), Carrara et al. (1991, 1995), Klimeš (2007), Metelka and Kycl (2007), Havlín et al. (2009, 2011), etc. The studies dealing with landslide hazard at Slovak territory are, for example, Pauditš and Bednarik (2002), Pauditš (2005), Pauditš et al. (2005), Pauditš and Bednarik (2006), Bednarik (2001, 2007, 2008), Bednarik et al. (2005), Jurko (2003), Magulová (2009), Dunčko (2011), etc.

The methodology of landslide hazard assessment using geostatistics and GIS is based on selection of most suitable parameters affecting the slope stability (geology, morphometric parameters, landuse, tectonics, hydrology, etc.). The methods for assessment of landslide hazard could be qualitative or quantitative. Qualitative methods represent assessment of the impact of individual factor on slope stability based on empirical experience. The significant share of quantitative methods is represented by statistical methods. They are based on exact observation of spatial distribution of existing landslides and causal parameters representing independent input variables. The result of statistical evaluation is spatial distribution of regions as a result of the synthesis of input parameters maps with the same level of landslide susceptibility. The most common statistical methods are bivariation and multivariation analysis.

In the presented work, we have focused on multivariation analysis. This method represents mutual combination of input parameters with the spatial distribution of existing landslides data. Using the simple spatial overlay of classified input parameters resulted in the creation of homogeneous condition unit (HCU) (Clerici, 2002; Süzen, Doyuran, 2004). In this case, the individual parameters were not assigned to any weights since the importance of such parameters has been given by its number and frequency of occurrence in various combinations. The result of such analysis is represented by a number of various combinations of HCU. The multivariation analysis also reflects, to some extent, the interactions between the individual input factors within the HCU. Input parameters (lithological units, land use, slope, average annual precipitation and landslides) were not weighted and thus no secondary reclassification or parameter weighting was necessary. The result was represented by the map of HCU. In the next step, the map of HCU was correlated with the map of actual landslide hazard and the frequency of occurrence of landslides within individual HCU calculated. Based on the density of landslides within each HCU we could classify a territory as follows:

1 Stable areas (no presence of landslides).

2 Conditionally stable areas (areas with potential for landslides when suitable conditions occur).

3-5 Non-stable areas (areas with various levels of landslide risk - low, medium, high landslide risk). 


\section{Study site and input parameters}

The Kysuce region is localised in north-west Slovakia on the border with Poland and Czech Republic (Fig. 1). According to geomorphological division of Slovak territory (Mazúr, Lukniš, 1986), the study area belongs to three regions: Stredné Beskydy Mts (units Kysucká vrchovina Mts, Kysucké Beskydy Mts), Západné Beskydy Mts (units Jablunkovské medzihorie Mts, Moravsko-sliezske Beskydy Mts and Turzovská vrchovina Mts) and Slovenskomoravské Karpaty Mts (unit Javorníky Mts). The most extended is the Kysucká vrchovina Mts. Its broken relief is determined by the presence of differentiated erosion-denudation processes that took place during quaternary period. These processes act very differently depending on the structure and lithological properties of rocks. The whole region is built of two main morphostructural units. The southern part belongs to the Klippen, the northern part to the outer Flysch belt. It is characterised by inner heterogeneity, which affects its significant vertical division (the hilly, under-upland/highland relief) (Potfaj, 2003). The region belongs to cool climatic region, including the moderately cool subregion. Local climate is characterised as moderately warm, very humid highlands. The land use is represented by a combination of hilly forest and upland and extensively used agricultural landscape with mostly scattered settlements with original agricultural function referred to as 'kopanice. The forest is a dominating element in the current landscape structure. In the past, beech was the dominant forest species together with the associated fir. Currently, the beech monocultures prevail. Mosaics of permanent grasslands (meadows and pastures), terraced fields, forests and non-forest wood vegetation are also present in the area (Miklós, Izakovičová, 2006).

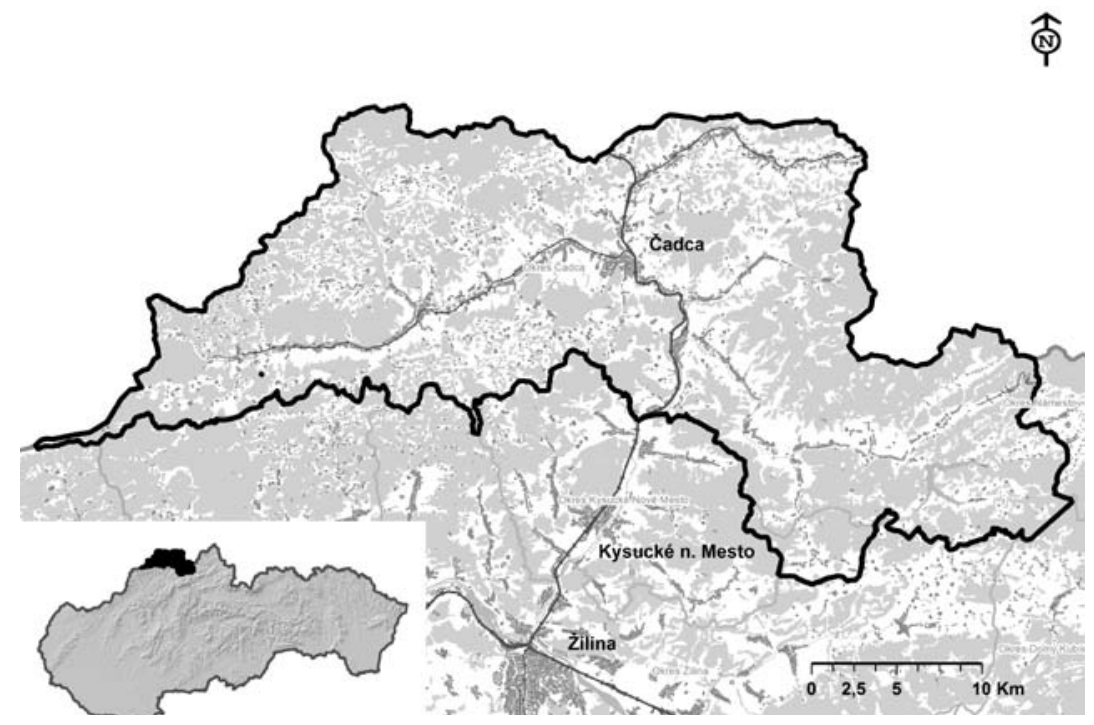

Fig. 1. Localisation of study site.

The input parameters were reclassified in order to unify their spatial extent. The following input parameters were considered:

\section{a) Lithology}

Lithology was elaborated using geological map in scale 1:50 000 (Potfaj et al., 2002). The map of lithology consisted of 29 lithological types, which were reclassified into 7 classes. Reclassification was based on similarity of lithogical units and engineering-geological properties of rock. Reclassified units are listed in Table 1.

The lithology of the Kysuce region represents the territory of almost the whole extent of the Kysuca river basin as far as the Kysuca Gate. In the structure of this region, the following units of the Western Carpathian Flysch Belt take part: the Silesian Unit, the Magura nappe and in the south the Klippen Belt. The Silesian nappe reaches the Kysuce region only in the northwest, at surface only the upper part of its bed sequence crops out - from the Istebna 
$\mathrm{T}$ a b l e 1. Reclassification of lithological types.

\begin{tabular}{|c|c|c|c|}
\hline Class & Lithological unit & Area (\%) & $\mathbf{k m}^{\mathbf{2}}$ \\
\hline 1 & Fluvial sediments & 6.20 & 69.54 \\
\hline 2 & Proluvial sediments & 0.63 & 7.16 \\
\hline 3 & Deluvial sediments & 20.66 & 231.62 \\
\hline 4 & Godula sequence & 3.25 & 36.50 \\
\hline 5 & Zlin formation & 31.73 & 355.65 \\
\hline 6 & Solan formation & 16.29 & 182.63 \\
\hline 7 & Bystrica unit & 20.45 & 229.26 \\
\hline 8 & Oravská Magura unit & 0.74 & 8.30 \\
\hline 9 & Klippen belt & 0.02 & 0.30 \\
\hline
\end{tabular}

Sandstones to the Krosno Formation - within the range of the Maastrichtian to Oligocene. From south on the Silesian Unit, the Magura nappe is overthrust in the form of a complicated imbricated and folded longitudinal body. Its lithofacial content is formed by several bed sequences, which were divided on the basis of their spatial distribution into partial lithofacial -tectonic zones as partial structural units. From north to south, thus, we describe the Raca (with two bed sequences), Bystrica and Oravska Magura partial units. The Klippen Belt as a young tectonic phenomenon joins the Magura nappe from the southern side. The contact of both structural units is tectonic and the contact surface is steep. The Klippen Belt in its course incorporates units of paleogeographically heterogeneous origin (Magura, Klape, Manin, Biele Karpaty Units, mostly outside the mapped region).

\section{b) Slope inclination}

The slope inclination was derived from digital elevation model with resolution of $25 \mathrm{~m}$. The output raster has been reclassified into six classes (Table 2). Slopes with inclination of more than $14^{\circ}$ cover $54 \%$ of the study area, slopes from $6^{\circ}$ to $14^{\circ}$ cover $35 \%$ of the study area.

$\mathrm{T}$ a b le 2. Slope reclassification.

\begin{tabular}{|c|c|c|c|}
\hline Class & Category & Area (\%) & $\mathbf{k m}^{\mathbf{2}}$ \\
\hline 1 & $0-2^{\circ}$ & 3.54 & 27.71 \\
\hline 2 & $2-6^{\circ}$ & 5.28 & 41.23 \\
\hline 3 & $6-10^{\circ}$ & 13.25 & 103.49 \\
\hline 4 & $10-14^{\circ}$ & 22.78 & 177.83 \\
\hline 5 & $14-19^{\circ}$ & 31.78 & 248.12 \\
\hline 6 & $>19^{\circ}$ & 23.34 & 182.23 \\
\hline
\end{tabular}

\section{c) Precipitation}

The precipitation parameters were interpreted according to Hofierka et al. (2002). This method was based on spatial interpolation of point data representing average annual precipitation using the regularised spline with tension. The precipitation values were recorded in 435 meteorological stations for the period 1976-1995. The lowest value at study area represents $869 \mathrm{~mm}$ and the maximum value is $1198 \mathrm{~mm}$. The average value represents $988 \mathrm{~mm}$. The final raster has been reclassified into five classes (Table 3). Almost half of the study area has precipitation between 980 and $1050 \mathrm{~mm} /$ year.

$\mathrm{T}$ a b l e 3. Reclassification of average annual precipitation values.

\begin{tabular}{|c|c|c|c|}
\hline Class & Category & Area (\%) & $\mathbf{k m}^{\mathbf{2}}$ \\
\hline 1 & $900-980$ & 17.52 & 137.88 \\
\hline 2 & $980-1050$ & 46.49 & 362.92 \\
\hline 3 & $1050-1130$ & 26.42 & 206.23 \\
\hline 4 & $1130-1200$ & 6.60 & 51.55 \\
\hline 5 & $1200-1280$ & 2.80 & 21.91 \\
\hline
\end{tabular}


The study area of Kysuce region belongs to wet climate region. The average annual precipitation reaches values between 950 and $1050 \mathrm{~mm}$. The highest average monthly precipitation is recorded in June and July. In Kysucká kotlina basin, the monthly average precipitation values reach 95-105 mm and in Hornokysucké podolie valley up to $120 \mathrm{~mm}$ (Soták et al., 2002). In the last decades, the average annual precipitation values and summer precipitation values have a decreasing trend (Table 4 ).

T a b l e 4. Average monthly and annual precipitation values ( $\mathrm{mm})$ in Čadca meteorological station.

\begin{tabular}{|l|c|c|c|c|c|c|c|c|c|c|c|c|c|}
\hline $\begin{array}{l}\text { Period/ } \\
\text { month }\end{array}$ & I & II & III & IV & V & VI & VII & VIII & IX & X & XI & XII & Year \\
\hline 1951-1980 & 56 & 53 & 50 & 66 & 88 & 121 & 126 & 100 & 67 & 58 & 66 & 65 & 915 \\
\hline $\mathbf{1 9 8 1 - 2 0 0 1}$ & 60 & 50 & 60 & 67 & 87 & 111 & 107 & 87 & 79 & 52 & 70 & 70 & 902 \\
\hline $\mathbf{2 0 0 2 - 2 0 1 1}$ & 61 & 47 & 47 & 47 & 104 & 91 & 124 & 82 & 62 & 56 & 56 & 57 & 834 \\
\hline
\end{tabular}

\section{d) Land use}

The land use types have been derived using the last CORINE-landcover data from year 2006. The original 17 landcover classes were reclassified into nine classes (Table 5). Most of the study area (52\%) is covered by coniferous forests, $18 \%$ is covered by mosaics and $9 \%$ by meadows and pastures.

$\mathrm{T}$ a b l e 5. Reclassified landcover.

\begin{tabular}{|c|l|r|r|}
\hline Class & \multicolumn{1}{|c|}{ Type } & \multicolumn{1}{c|}{ Area (\%) } & \multicolumn{1}{c|}{$\mathbf{k m}^{\mathbf{2}}$} \\
\hline 1 & Impervious surfaces & 4.83 & 37.71 \\
\hline 2 & Arable land & 3.67 & 28.70 \\
\hline 3 & Meadows and pastures & 9.16 & 71.50 \\
\hline 4 & Mosaics & 18.37 & 143.44 \\
\hline 5 & Deciduous forests & 1.80 & 14.11 \\
\hline 6 & Coniferous forests & 51.85 & 404.72 \\
\hline 7 & Mixed forests & 4.25 & 33.21 \\
\hline 8 & Non-forest woody vegetation & 5.83 & 45.58 \\
\hline 9 & Water bodies & 0.19 & 1.53 \\
\hline
\end{tabular}

\section{e) Landslides}

The landslides represent the most important analytical input parameter. According to Clerici (2002), we have used a total length of landslide detachment line. Using this approach it is possible to derive statistically more representative values. When analysing a total landslide area, it is possible that accumulation part of certain landslide extends to other lithological unit than detachment line. The original map of landslide localisation (Jezný et al., 2003) has been vectorised and converted into grid with resolution of $25 \mathrm{~m}$. The total landslide length is defined by 12193 grid cells. Concerning the grid resolution, the total length of detatchment lines represents $307.87 \mathrm{~km}$. The detachment lines' length varies from 33 to $1912 \mathrm{~m}$ ( $260 \mathrm{~m}$ in average). Almost $83 \%$ of detachment lines belong to the class with length between 33 and $400 \mathrm{~m}$ with a total length of $175.93 \mathrm{~km}$. Remaining $17 \%$ belong to the group with length more than $401 \mathrm{~m}$ with a total length of $131.93 \mathrm{~km}$.

Landslides represent the type of slope deformation which is most sensitive to climate and other natural and anthropogenic factors variability. A big amount of landslides belong to slope depressions of Godula sequence of Silesian unit covering an area of $36.5 \mathrm{~km}^{2}$. The landslides cover $7.4 \mathrm{~km}^{2}$ of this unit, which represent almost $20 \%$. The most extended geological unit is represented by Zlín Formation covering $355.6 \mathrm{~km}^{2}$ where landslides represent $12.29 \%\left(43.7 \mathrm{~km}^{2}\right)$. Less than $10 \%$ of landslides cover Bystrica unit and Solán Formation.

Landslides cover a total area of $148.3 \mathrm{~km}^{2}$ from a total study area of $780.6 \mathrm{~km}^{2}$, which represents $19 \%$. The most extended are potential landslides covering an area of $101.2 \mathrm{~km}^{2}(12.9 \%)$. The active landslides cover an area of 1.8 $\mathrm{km}^{2}(0.24 \%)$ and stable landslides cover $45.8 \mathrm{~km}^{2}(5.86 \%)$. 
Most of the landslides are located on deluvial deposits, covering $55.2 \mathrm{~km}^{2}$. Active landslides cover $0.9 \mathrm{~km}^{2}$, potential landslides $37.5 \mathrm{~km}^{2}$ and stable landslides cover $16.3 \mathrm{~km}^{2}$ of this geological formation. About $20 \%$ is covered by landslides of Godula sequence $\left(7.4 \mathrm{~km}^{2}\right)$. Potential landslides cover $3.6 \mathrm{~km}^{2}$ and stable landslides cover $3.8 \mathrm{~km}^{2}$. Landslides on Zlin and Soláň Formations and Bystrica unit cover 8-12\%.

\section{Results and discussion}

In order to assess the landslide risk of the study area, quantitative and partially qualitative definition of causes, development and landslide probability occurrence has been analysed. Analytical input parameters consisted of four variables (independent variables) and landslides (dependable variables). Statistical analysis resulted in 15988 combinations of input parameters representing the HCU. From this amount, 2002 were affected by landslides, and the rest of HCUs (13 986) were not affected. The total HCU area affected by landslides represents $156.92 \mathrm{~km}^{2}(20.12 \%)$. This area has been spatially extrapolated using the causal factors of affected polygons. Due to the fact that slope stability is primary controlled by lithology and slope inclination, the result was corrected by hardening the rules of statistical reclassification. Thus, the correction resulted in delineation of conditionally stable areas. They are represented by polygons with conditions suitable for the occurrence of landslides. Following this, additional reclassification was applied to all areas located on flysch with prevailed clay minerals and their mantle deluvia with slope inclination higher than $6^{\circ}$. Stable areas covered $623.01 \mathrm{~km}^{2}(79.8 \%)$, and conditionally stable areas covered $228.77 \mathrm{~km}^{2}$ (29.33\% out of this area). Unstable areas were divided into three levels of landslide risk - low, medium and high risk. Low landslide risk represents an area of $111.19 \mathrm{~km}^{2}(14.3 \%)$, medium risk $29.7 \mathrm{~km}^{2}$ (3.8\%) and high risk represents $16.01 \mathrm{~km}^{2}$ (2\%) (Fig. 2).

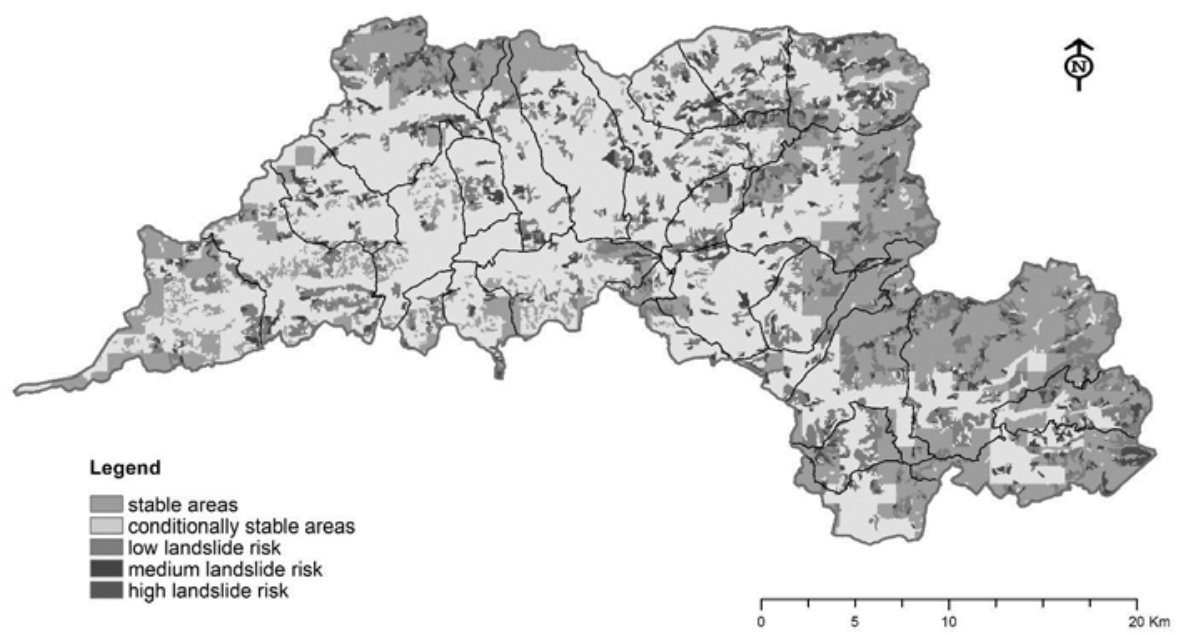

Fig. 2. Landslide risk in the study region. 
The landslide risk was also aggregated on level of individual cadastral areas (Fig. 3). The most exposed are cadastral areas of Klubina, Čierne, Horelica and Svrčinovec villages. Medium landslide risk is present mostly in Skalité (10\%) and also Riečnica, Svrčinovec and Harvelka villages, covering more than $6 \%$ of their cadastral area. Twenty-five percent of the cadastral area of Radôstka village is under low risk. More than 19\% under low risk is characterised by Zborov nad Bystricou, Harvelka, Nová Bystrica, Horelica, Svrčinovec and Stará Bystrica villages.

Conditionally stable areas cover more than $50 \%$ in cadastral areas of Olešná II, Nová Bystrica and Klubina villages. Twenty-five percent of conditionally stable areas are present in cadastral areas of Klokočov, Dlhá nad Kysucou, Zborov nad Bystricou, Radôstka, Skalité, Lutiše, Stará Bystrica, Makov, Oščadnica, Harvelka and Riečnica villages. These cadastral areas represent almost half of cadastral areas of Kysuce region.

Most stable areas are Podvysoká (97\%), Turzovka (81\%), Olešná I. (80\%), Raková, Staškov, Korňa, Krásno nad Kysucou villages (more than 70\%), Klokočov, Horelica, Čierne, Dlhá nad Kysucou, Svrčinovec, Vysoká nad Kysucou, Zákopčie, Dunajov, Turkov and Čadca villages (more than 50\%).

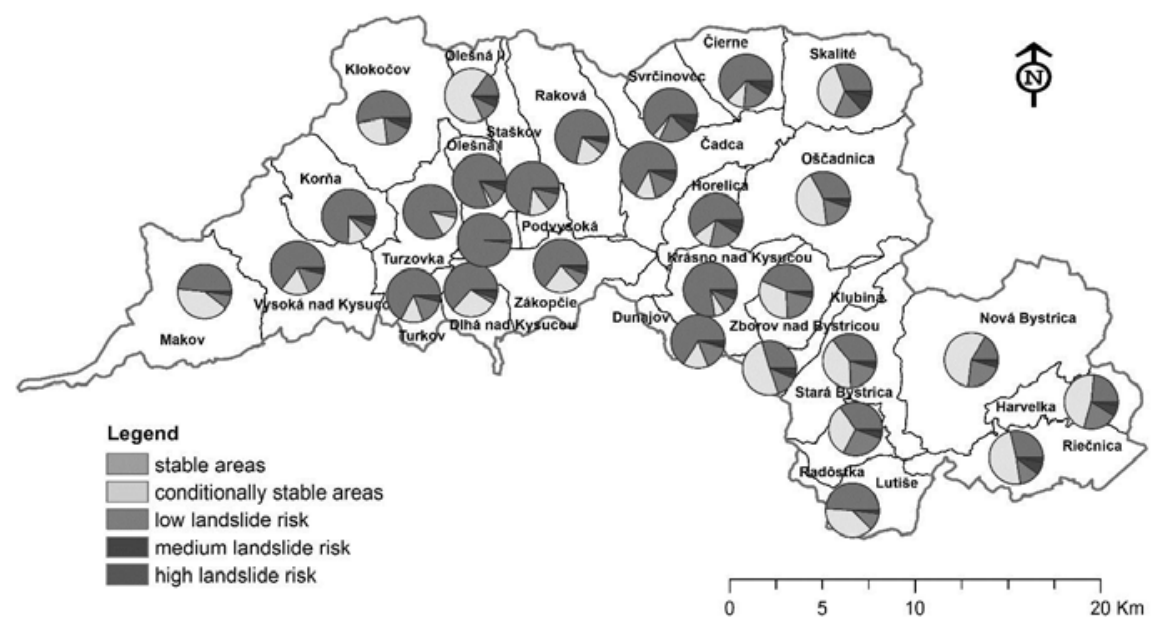

Fig. 3. Landslide risk aggregated on level of cadastral areas.

Concerning the analysis of input landslide causal factors, the individual HCUs are characterised as follows (Fig. 4). The largest area under low landslide risk is located on Zlín Formation and Bystrica unit. Slopes in the range of $14-19^{\circ}$ prevail on Zlín Formation, while Bystrica unit is characterised by prevailing slopes higher than $19^{\circ}$ within this risk class. The prevailing combination in this risk class is coniferous forests and average annual precipitation between 980 and $1050 \mathrm{~mm}$. The medium landslide risk areas are also mostly located on Zlín Formation and deluvial deposits with slopes ranging between $14^{\circ}$ and $19^{\circ}$ and the cover represented by coniferous forests or mosaics respectively. Zlín Formation and Bystrica unit prevail on high 
landslide risk areas with slopes in the range of $14-19^{\circ}$ and higher. The prevailing average annual precipitation in this risk class is $1050-1130 \mathrm{~mm}$. Landcover is mostly represented by coniferous forests. The conditionally stable areas cover almost one-third of the study area, located mostly on Zlín Formation and Bystrica unit and slopes higher than $14^{\circ}$. Prevailing land use is characterised by coniferous forests with precipitation between 980 and $1050 \mathrm{~mm}$.
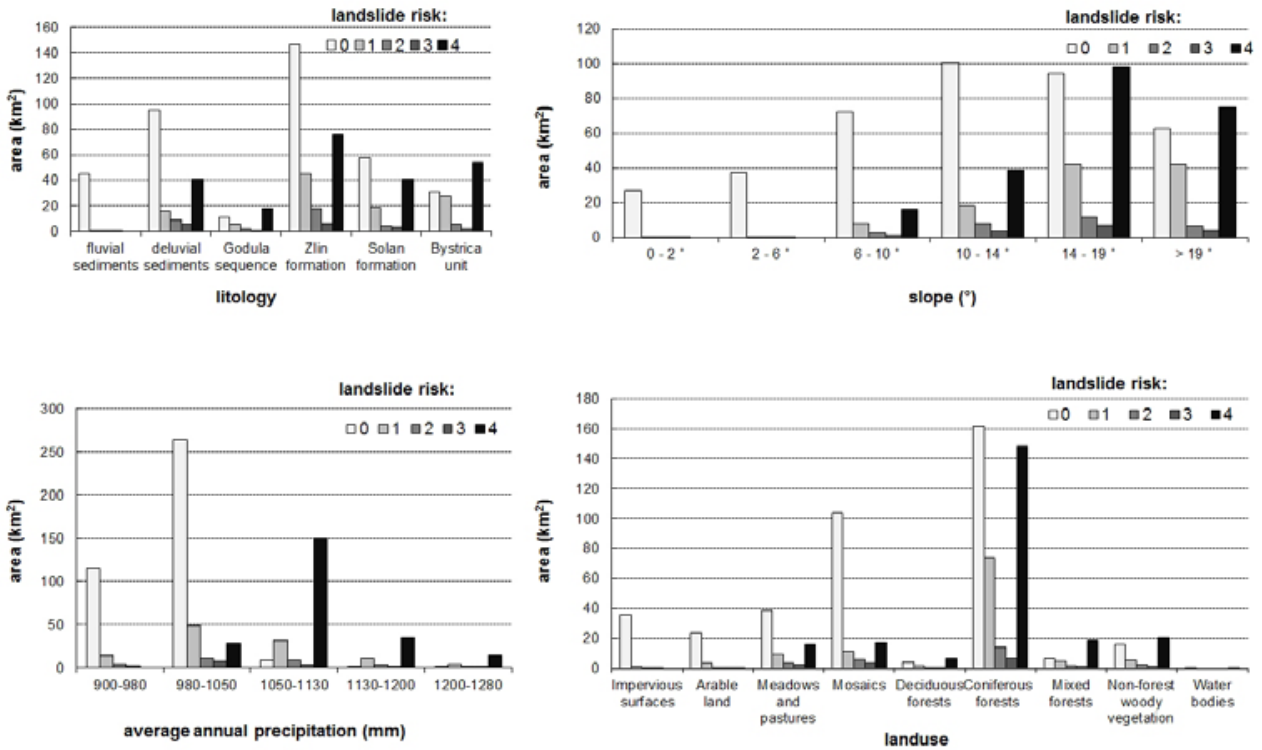

Fig. 4. Landslide risk and causal factors.

Since Zlín Formation covers approximately one-third of the study area, it also influences the overall landslide risk assessment. This lithological formation covers the largest area within all landslide risk classes as well as in conditionally stable areas. The most frequent slope class is $14-19^{\circ}$. The higher susceptibility of Zlín Formation to landslides is caused mainly by the different geomorphological value of claystone and sandstone sequence. The higher share of claystone results in higher susceptibility of this formation to exogenous degradation processes. They are mostly degradated due to frequent imbitition and drying processes resulting from higher precipitation rates. The most frequent reason for occurrence of slope deformations on flysch is exceeding the strength of claystone and marlstone in weathering zone and increasing water's lift force. Increasing water's lift force is related to decreased evaporation and long-term precipitation during autumn and spring months and snow melt season.

\section{Conclusion}

The methodology presented in this study is based on selection of most suitable parameters affecting the slope stability (geology, morphometric parameters, land use, tectonics, hydrology, etc.). This methodology represents a multivariation approach based on mutual combination 
of input parameters with the spatial distribution of existing landslides data. The result of such analysis is represented by a number of various combinations of homogeneous conditions units (HCUs). The units were then classified according to density of actual landslides as nonstable areas (areas with various levels of landslide risk - low, medium, high landslide risk). Furthermore, areas with no presence of actual landslides but suitable conditions were classified as conditionally stable areas. Such approach helps predict the occurrence of new slope deformations in the future and could be used as a valuable decision-making tool in land use planning processes. However, the results should be interpreted with care since they depend to a high extent on the resolution and quality of input data. For instance, in our case, the resolution of the precipitation data was originally downscaled from $1 \mathrm{~km}$ grid to the actual resolution of $25 \mathrm{~m}$. Thus, the availability of higher accuracy data, especially digital elevation model and precipitation data, would significantly improve the landslide susceptibility model.

\section{Acknowledgements}

The contribution was prepared within the grant project of the Ministry of Education of the Slovak Republic and the Slovak Academy of Sciences No. 2/0158/14 "Diversity of agricultural landscape and its ecosystem services".

\section{References}

Bednarik, M. (2001). Assessment of the landslides susceptibility in the territory of Handlovská koltina basin (in Slovak). Unpublished diploma thesis, Comenius University, Faculty of Natural Sciences, Bratislava.

Bednarik, M., Clerici, A., Tellini, C. \& Vescovi P. (2005). Using GIS GRASS in evaluation of landslide susceptibility in Termina valley in the Northern Appennines (Italy). In Proceedings of the Conference on Engineering Geology: Forum for young engineering geologists, 6-9 April 2005 (pp. 19-24). DGGT Erlangen-Nürnberg: FridrichAlexander-University of Erlangen-Nürnberg.

Bednarik, M. (2007). Assessment of landslide risk for the requirement of spatial planning documentation (in Slovak). Unpublished doctoral dissertation, Comenius University, Faculty of Natural Sciences, Bratislava.

Bednarik, M. (2008). Assessment of landslide hazard on the railroad Královany - Liptovský Mikuláš (in Slovak). Unpublished graduation thesis, Comenius University, Faculty of Natural Sciences, Bratislava.

Carrara, A. (1983). Multivariate models for landslide hazard evaluation. Mathematical Geology, 15(3), 403-427.

Carrara, A. (1988). Landslide hazard mapping by statistical methods: a „Black Box“ approach. In Proceedings of workshop on Natural Disaster in European Medditerranean Countries, 27 June -1 July 1988 (pp. 205-224). Genoa: Consiglio Nazionale delle Ricerche.

Carrara, A., Cardinalli, M., Detti, R., Guzzetti, F., Pasqui, V. \& Reichenbach P. (1991). GIS techniques and statistical models in evaluating landslide hazard. Earth Surface Processes and Landforms, 16(5), 427-445. DOI: 10.1002/ esp.3290160505.

Carrara, A., Cardinalli, M., Guzzetti, F. \& Reichenbach P. (1995). GIS technology in mapping landslide hazard. Geographical Information Systems in Assessing Natural Hazards, 5, 135-175. DOI: 10.1007/978-94-015-8404-3_8.

Clerici, A. (2002). A GRASS GIS based shell script for landslide susceptibility zonation by the conditional analysis method. In Proccedings of the Open source GIS - GRASS users conference 2002, 11-13 September 2002, Trento, Italy. http://www.ing.unitn.it/ grass/conference/GRASS2002/proceedings/proceedings/pdfs.

Dunčko, M. (2011). Vulnerability assessment of the linear construction in GIS environment (in Slovak). Juniorstav, 6.3 Kartografie a GIS, 1-5.

Havlín, A., Bednarik, M. \& Urbanová K. (2009). Asssessment of landslide risk in the Silesia-Slovak border-landslides do not respect boundaries (in Czech). In Sborník Svahové deformace a pseudokras, 13-15 May 2009 (pp. 1-28). Vsetín: Česká geologická služba, Ústav struktury a mechaniky hornin, AVČR.

Havlín, A., Bednarik, M., Magulová, B. \& Vlčko J. (2011). Using logistic regression for assessment of susceptibility to landslides in the middle part of Chřib (Czech Republic) (in Czech). Acta Geologica Slovaca, 3(2), 153-161. 
Hofierka, J., Parajka, J., Mitašová, H. \& Mitáš L. (2002). Multivariate Interpolation of Precipitatio Using Regularized Spline with Tension. Transactions in GIS, 6(2), 135-150. DOI: 10.1111/1467-9671.00101.

Jezný, M., Potfaj, M., Šlepecký, T., Beleš, F., Sandanus, M., Vondráček, L., Hanzel, V., Kandera, K., Čurlík, J., Šefč́́k, P., Martinčeková, T. \& Januš J. (2003). Set of regional maps of geological environmental factors of the Kysuce basin in scale $1: 50000$ (in Slovak). Bratislava: ŠGÚDŠ.

Jurko, J. (2003). Map of landslides susceptibility in the Liptovská kotlina basin (in Slovak). Unpublished diploma thesis, Comenius University, Faculty of Natural Sciences, Bratislava.

Klimeš, J. (2007). Analysis of the conditions of slope deformations in the Vsetinske vrchy Mts (in Czech). Unpublished diploma thesis, Charles University, Prague.

Kopecký, M., Ondrášik, M., Martinčeková, T. \& Šimeková J. (2008). Atlas of slope stability in the Slovak Republic in scale 1:50000 (in Slovak). Bratislava: ŠGÚDŠ.

Magulová, B. (2009). Using GIS for creation of geohazards map as a base for landuse planning (in Slovak). Acta Geologica Slovaca, 1(1), 25-32.

Mazúr, E. \& Lukniš M. (1986). Geomorphological division of SSR and ČSSR. Part Slovakia (in Slovak). Bratislava: Slovenská kartografia.

Metelka, V. \& Kycl P. (2007). Mapping of slope landslides susceptibility in GIS environment, Miramar, Kostarika (in Czech). In Sborník Svahové deformace a pseudokras, 29-31 May 2007 (pp. 1-15). Vsetín: Česká geologická služba, Ústav struktury a mechaniky hornin, AVČR.

Miklós, L. \& Izakovičová Z. (2006). Atlas of representative geoekosystems of Slovakia (in Slovak). Bratislava: Ústav krajinnej ekológie SAV.

Pauditš, P. \& Bednarik M. (2002). Using GIS in evaluation of landslide susceptibility in Handlovská kotlina basin. In Proceedings of the 1st European conference on landslide, 24-26 June 2002 (pp. 437-441). Praha: Swets \& Zeitlinger, Lisse.

Pauditš, P. (2005). Assessment of territory susceptibility to landslides using statistical methods in GIS environment. Unpublished doctoral dissertation, Comenius University, Faculty of Natural Sciences, Bratislava.

Paudiť̌, P., Vlčko, J. \& Jurko J. (2005). Statistic methods in landslide hazard assessment (in Slovak). Mineralia Slovaca, 37(4), 529-538.

Pauditš, P. \& Bednarik M. (2006). Different interpretations of slope deformatios in the statistical evaluation of the landslide hazard (in Slovak). In Geológia a životné prostredie, 14-15 June 2006 (pp. 1-10).

Potfaj, M., Maglay, J., Šlepecký, T. \& Teták F. (2002). Geological map of the Kysuce region 1: 50000 (in Slovak). Bratislava: ŠGÚDŠ.

Potfaj, M. (Ed.) (2003). Notes to the geological map of the Kysuce region (in Slovak). Bratislava: ŠGÚDŠ.

Soták, Š., Liová, S. \& Borsányi P. (2002). Expression of climate variability on the hydrological regime of streams in the Kysuce region. In XIV. Česko-slovenská bioklimatologická konference, 2-4 October 2002 (pp. 389-400). Lednice na Moravě.

Süzen, M.L. \& Doyuran V. (2004). A comparison of the GIS based landslide susceptibility assessment methods: multivariate versus bivariate. Environmental Geology, 45(5), 665-679. DOI: 10.1007/s00254-003-0917-8. 